\title{
Diversity and distribution of Tardigrada in Arctic cryoconite holes
}

\author{
Krzysztof ZAWIERUCHA, ${ }^{1 *}$ Marta OSTROWSKA,${ }^{2}$ Tobias R. VONNAHME,${ }^{3}$ Miloslav DEVETTER,${ }^{4}$ \\ Adam P. NAWROT, ${ }^{5,6}$ Sara LEHMANN, ${ }^{7}$ Małgorzata KOLICKA ${ }^{1}$
}

${ }^{1}$ Department of Animal Taxonomy and Ecology, Adam Mickiewicz University, Umultowska 89, 61-614 Poznań, Poland; ${ }^{2}$ Department of Avian Biology and Ecology, Adam Mickiewicz University, Umultowska 89, 61-614 Poznań, Poland; ${ }^{3}$ Max-Planck Institute for Marine Microbiology, Bremen, Germany; ${ }^{4}$ Institute of soil Biology, Biology Centre CAS, Na Sádkách 7, 37005 České Budějovice, Czech Republic; ${ }^{5}$ Institute of Geophysics, Polish Academy of Sciences, Warsaw, Poland; ${ }^{6}$ forScience Foundation, Poland; ${ }^{7}$ Department of Analytical Chemistry, Chemical Faculty, Gdansk University of Technology, Poland

*Corresponding author: k.p.zawierucha@gmail.com.

\begin{abstract}
Despite the fact that glaciers and ice sheets have been monitored for more than a century, knowledge on the glacial biota remains poor. Cryoconite holes are water-filled reservoirs on a glacier's surface and one of the most extreme ecosystems for micro-invertebrates. Tardigrada, also known as water bears, are a common inhabitant of cryoconite holes. In this paper we present novel data on the morphology, diversity, distribution and role in food web of tardigrades on Arctic glaciers. From 33 sampled cryoconite holes of 6 glaciers on Spitsbergen, in 25 tardigrades were found and identified. Five taxa of Tardigrada (Eutardigrada) were found in the samples, they are: Hypsibius dujardini, Hypsibius $s p$. A, Isohypsibius $s p$. A., Pilatobius recamieri, and one species of Ramazzottiidae. H. dujardini and $\mathrm{P}$. recamieri were previously known from tundra in the Svalbard archipelago. Despite the number of studies on Arctic tundra ecosystems, Hypsibius sp. A, one species of Ramazzottiidae and Isohypsibius $s p$. A are known only from cryoconite holes. Tardigrade found in this study do not falsify the hypothesis that glaciers and ice sheets are a viable biome (characteristic for biome organisms assemblages - tardigrades). Diagnosis of Hypsibius sp. A, Isohypsibius sp. A, and species of Ramazzottiidae with discussion on the status of taxa, is provided. To check what analytes are associated with the presence of tardigrades in High Arctic glacier chemical analyses were carried out on samples taken from the Buchan Glacier. pH values and the chemical composition of anions and cations from cryoconite holes water from the Buchan Glacier are also presented. The current study on the Spitsbergen glaciers clearly indicates that tardigrade species richness in cryoconite holes is lower than tardigrade species richness in Arctic tundra ecosystems, but consists of unique cryoconite hole species. As cryoconite tardigrades may feed on bacteria as well as algae, they are primary consumers and grazers - secondary consumers of the decomposer food chain in this extreme ecosystem.
\end{abstract}

Key words: Buchanbreen; Hansbreen; glacial biome; Svalbard; Tardigrada; unique species.

Received: February 2016. Accepted: May 2016.

\section{INTRODUCTION}

The most recent Intergovernmental Panel on Climate Change assessment (Vaughan et al., 2013) emphasized the importance of glaciers in terms of the Earth's ecosystem and underlined their containing a significant amount $(70 \%)$ of the Earth's water in the frozen state (ACIA, 2006). Besides, glaciers also constitute an important habitat for microorganisms (Porazińska et al., 2004; Hodson et al., 2008; Edwards et al., 2011; Kaczmarek et al., 2016; Zawierucha et al., 2015a), which is why glaciers and ice sheets can be treated as a distinct glacial biome where cryoconite holes make up small ecosystems (Anesio and Laybourn-Parry, 2012). Cryoconite holes are water-filled reservoirs that occur on glacier surfaces throughout the world. The development and functioning of these habitats is possible because of the decrease in albedo on the surfaces of mineral and organic dust-covered glaciers, the presence of cryophilic microorganisms and the existence of simple trophic webs (McIntyre, 1984; Takeuchi et al., 2001; Hod- son et al., 2008; Zawierucha et al., 2015a; Cook et al., 2016b). Cryoconite holes are still poorly known extreme habitats, therefore the interest in them is increasing, especially in biological sciences (Dabert et al., 2015; Bagshaw et al., 2016a, 2016b; Cook et al., 2016a, 2016b; Kaczmarek et al., 2016). Svalbard archipelago is the most glaciated region of the European Arctic (Hagen, 1993). The history of studies the high Arctic Svalbard archipelago fauna starts at beginning of the twentieth century, and, to date, ca. 1000 limnoterrestrial species have been identified from this area, including new species for science (Zawierucha, 2013; Coulson et al., 2014; Kiedrowicz et al., 2016). Surprisingly, faunistic studies on glacial fauna in this region are limited (Dastych, 1985; De Smet and Van Rompu, 1994; Zawierucha et al., 2015a).

One of the taxa known to inhabit glaciers in the Arctic, Antarctic, Himalayas and Alps are tardigrades, which are well adapted to survive extreme conditions, including glacial environments (Dastych et al., 2003; Zawierucha et 
al., 2015a). The phylum, Tardigrada, presently consists of over 1200 species (Degma et al., 2011; Vicente and Bertolani, 2013) that inhabit terrestrial (soil, plants, leaf litter) and aquatic (freshwater and marine sand, mud and plants) environments across the globe (Ramazzotti and Maucci, 1983; Nelson et al., 2015). The understanding of the diversity and distribution of glacial tardigrades is limited (Zawierucha et al., 2015a). So far, research on Svalbard has focused primarily on limno-terrestrial tardigrades (Węglarska, 1965; Dastych, 1985) rather than on the typically aquatic ones (De Smet et al., 1987). Thus, till now, just four tardigrade species have been found from cryoconite holes on Svalbard (Dastych, 1985; De Smet and Van Rompu, 1994).

A biome is a large independent category of ecosystems with characteristic animal and plant assemblages adapted to the general conditions of the region (Purves, 2007). A glacial biome is typified by truncated food webs and distinctive biogeographical structures (landscape features). This biome encompasses habitats with low temperatures, such as the ice surface, subglacial and englacial environments, and snow (Anesio and Laybourn-Parry, 2012). Unexpectedly, data on the animal assemblages in a glacial biome are extremely limited (Zawierucha et al., 2015a).

In this paper, the diversity and distribution of tardigrades inhabiting glaciers in Spitsbergen, with discussion on the food web and the glacial biome hypothesis, is presented.

\section{METHODS}

\section{Study area}

The Svalbard archipelago (Fig. 1) is situated at 74$81^{\circ} \mathrm{N}$ and $10-30^{\circ} \mathrm{E}$ in the European High Arctic. This region lies at the boundary between the Greenland Sea and the Barents Sea. During the last few hundred thousand years, Svalbard has been covered by extensive ice sheets several times (Lonne and Lysa, 2005). During the last ice age, almost the entire archipelago was covered by ice. After the glacial retreat, a landscape without soil or veg-

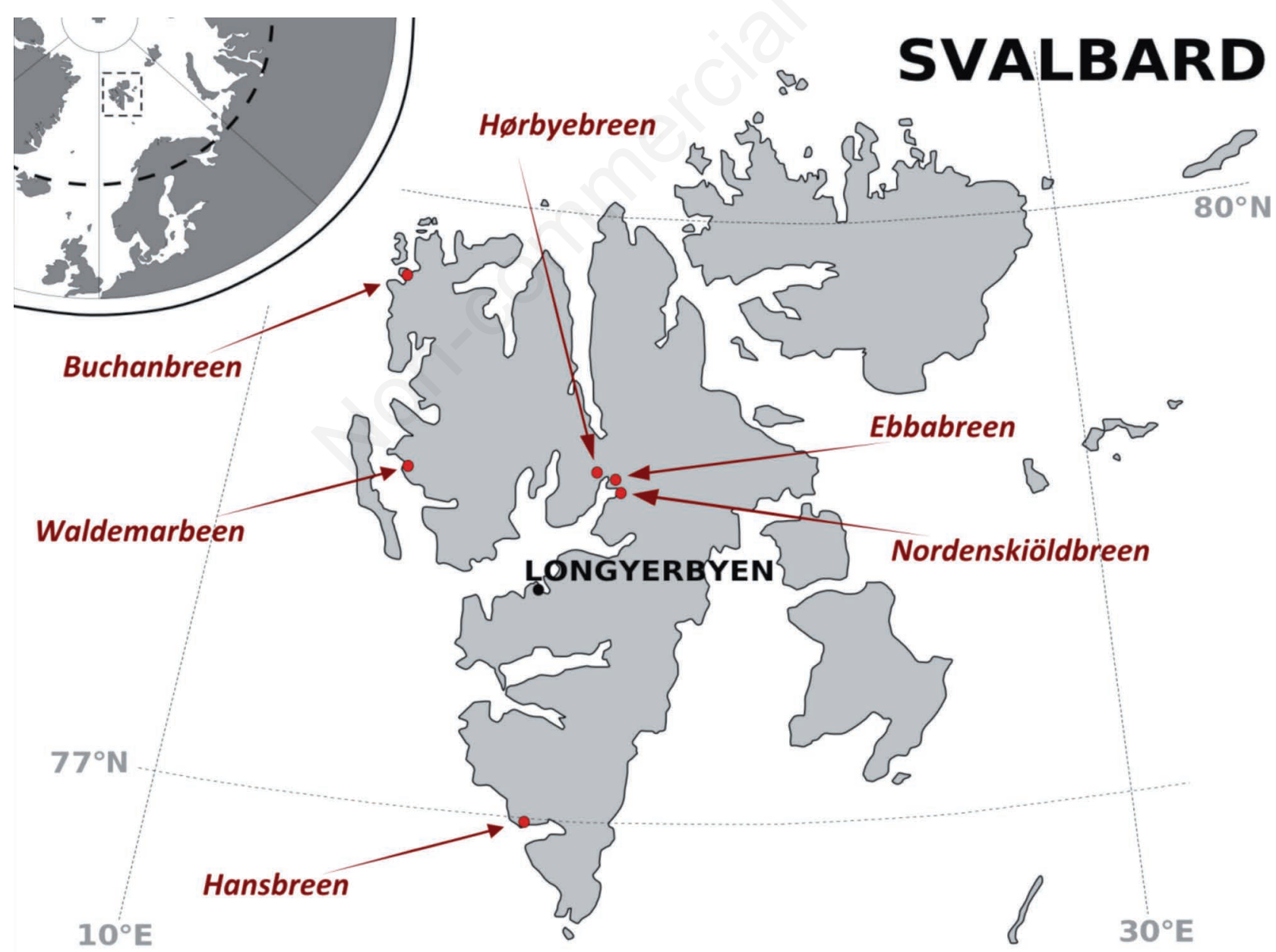

Fig. 1. Svalbard archipelago with sampled glaciers. 
etation was left behind (Mangerud and Svendsen, 1992; Hjelle, 1993).

Presently, glaciers and ice caps cover $59 \%\left(36.6 \mathrm{~km}^{2}\right)$ of the $61.7 \mathrm{~km}^{2}$ area of the Svalbard archipelago (Hagen et al., 2003). Rugged mountains and coastal lowlands are typical for this geologically young region where the present summer landscape is dominated by running water and mass wasting (Owczarek et al., 2014). Svalbard has a treeless landscape, composed of tundra ecosystems that are simple and fragile based on the harsh climate and low energy budget (Jonsdottir, 2005). The increases in temperature and changes in precipitation influence both the biotic and abiotic components of fluvial systems (Callaghan and Tweedie, 2011; Owczarek et al., 2014). Małecki et al. (2013) stated that climatic conditions on Svalbard are relatively mild compared to other high Arctic sites - the mean temperature of the summer period (June-August) at Svalbard Airport (Longyearbyen) is $4.9^{\circ} \mathrm{C}(1981-2010)$, while during the coldest month (February), mean temperatures of $-13.5^{\circ} \mathrm{C}$ have been recorded (based on data from the Norwegian Meteorological Institute). As a result of the West Spitsbergen Current, the west part of the archipelago is warmer and more humid than other areas of similar latitude (Głowacki, 2007).

\section{Glaciers}

All samples were taken from Spitsbergen, which is the largest island of the Svalbard archipelago (Figs. 1,2). The Hans Glacier is located in the Hornsund Fjord, where, because of the West Spitsbergen Current, local oceanic climate has more precipitation and higher air temperatures then in the area of Isfjord and Dickson Land (Głowacki, 2007).

The Dickson Land glaciers, like the Ebba Glacier, Hørbye Glacier and Nordenskiöld Glacier, are situated in the central part of Spitsbergen, in Billefjorden (Petuniabukta). This region is characterized by an inner-fjord climate type, meaning arid conditions and higher annual thermal contrasts (Rachlewicz and Styszyńska, 2007; Rachlewicz, 2009). Local glaciers may be therefore more exposed to high temperatures and less precipitation, including the coast of the Spitsbergen island, between the Oscar II Land and the Prins Karls Forland island. Compared to the central part of Spitsbergen, precipitation is twice as high. Mean air temperature is slightly higher (by $0.1^{\circ} \mathrm{C}$ ) than at Svalbard Airport and significantly lower (by $1.1^{\circ} \mathrm{C}$ ) than at Hornsund (Przybylak and Araźny, 2005).

The Waldemar Glacier is situated in the northern part of the Oscar II Land, Kaffiøyra, northwestern Spitsbergen (Sobota, 2009). The mean summer air temperature (19752010) is $4.9^{\circ} \mathrm{C}$ and the average sum of precipitation (1975-2010) is $46.5 \mathrm{~mm}$ (Przybylak et al., 2011).

The Buchan Glacier is located at the northern site of the Magdalenefjorden. Based on the air temperature dis- tribution maps provided by Przybylak et al. (2014), the annual air temperature in Magdalenefjorden is lower by approximately $1.5^{\circ} \mathrm{C}$ than at Svalbard Airport.

\section{Sample collection, preservation and specimen determination}

Cryoconite material was collected from six glaciers on Spitsbergen: 10 samples from Hans Glacier (July 2014), three samples from Ebba Glacier (August 2012), five from Hørbye Glacier (August 2013, July and August, 2014), ten from Nordenskiöld Glacier (July and August, 2014), three samples from Buchan Glacier (28 July, 2013), and two samples from Waldemar Glacier ( $4^{\text {th }} \mathrm{Au}-$ gust, 2013) (Figs. 1, 2). Samples from Hans Glacier were collected with disposable plastic Pasteur pipettes and transferred to $15 \mathrm{~cm}^{3}$ plastic test tubes. Samples were collected in such a manner that the sediment from the bottom of the cryoconite holes was taken. Following collection, the samples were preserved using $96 \%$ ethylene alcohol. From each sample, $1 \mathrm{~cm}^{3}$ of sediment was scanned for tardigrades with a stereomicroscope.

Cryoconite holes on three glaciers around Billefjorden were collected employing a plastic siphon, sucking all the cryoconite sediment within a $4.5 \mathrm{~cm}$ plastic ring (area 15 $\mathrm{cm}^{2}$ ) from a second plastic siphon into a $0.5 \mathrm{dm}^{-3}$ polyethylene bottle. All sampling equipment was washed with meltwater of the sampling site prior to the sampling. In the laboratory, the samples were sedimented, the supernatant was removed and a subsample was counted in a counting chamber under stereomicroscope. Cryoconite holes on the Buchan Glacier and Waldemar Glacier were collected by hand and placed in plastic boxes, then fixed with formaldehyde. The number of samples (N), GPS coordinates, and elevation above sea level (ASL) are presented in Tabs. 1 to 3. Reference system of the GPS coordinates is WGS 84 .

Densities of the tardigrades from Hans Glacier and glaciers in Billefjorden are presented in Zawierucha et al. (2016b). However, the number of analysed samples from Billefjorden in the present study is different. Some of the samples that were analysed in terms of abundance are currently not available for taxonomic and faunistic analysis. Because of losing a piece of material during sampling, quantitative data from cryoconite holes from Buchan and Waldemar Glaciers were omitted in Zawierucha et al., (2016b). In total, we analysed 33 samples in terms of tardigrade diversity (instead of the 48 mentioned in Zawierucha et al., 2016b).

All tardigrades and their exuvia with eggs were mounted on microscopic slides in Hoyer's medium and polyvinyl alcohol, and then examined with a phase contrast microscope (PCM), Olympus, model BX53. The species were identified using the key to the World Tardigrada (Ramazzotti and Maucci, 1983) and compared 
with other original papers (Morgan, 1975; Dastych, 1985, 1988; Miller et al., 2005). Macroplacoid length sequences are given according to Kaczmarek et al. (2014). Tardigrade taxonomy is presented according to Bertolani et al. (2014). Trophic groups were established based on the scheme presented in Guil and Sanchez-Moreno (2013). The abbreviation ZMUC in the text refers to the Museum of Natural History, Copenhagen, Denmark.

\section{Chemical analysis}

Chemical analyses were made strictly for samples taken from the Buchan Glacier, to check what analytes are associated with the presence of tardigrades in High Arctic glacier and to compare our results with data from Antarctic presented in Porazińska et al. (2004). Water samples were collected in $0.12 \mathrm{dm}^{-3}$ bottles and stored at $3^{\circ} \mathrm{C}$ in
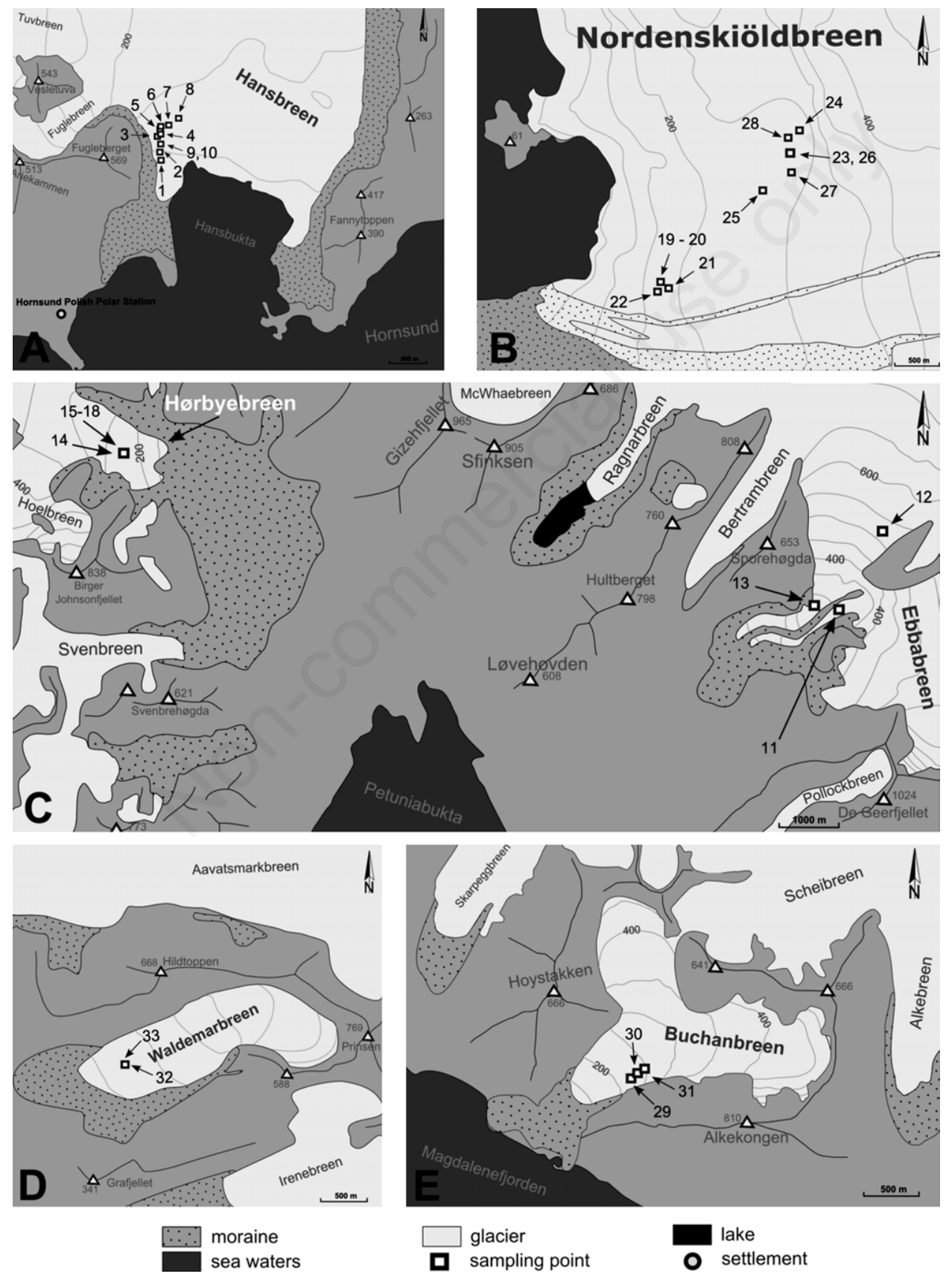

Fig. 2. Glaciers with sampled points. A, Hans Glacier; B, Nordenskiöld Glacier; C, Ebba Glacier, Hørbye Glacier; D, Waldemar Glacier; E, Buchan Glacier. 
Tab. 1. List of cryoconite samples from Hans Glacier with GPS coordinates, elevation, number of individuals determined to species/genus level. All samples were collected on 30.07.2014. For sampling sites localities see Figs. 1 and 2.

\begin{tabular}{|c|c|c|c|c|}
\hline $\mathbf{N}$ & GPS & Elevation (m) & P. recamieri & Hypsibius sp. A \\
\hline 1 & $\mathrm{~N} 77^{\circ} 01.204^{\prime} \mathrm{E} 15^{\circ} 35.740^{\prime}$ & 23 & 2 & 2 \\
\hline 2 & $\mathrm{~N}^{\prime} 7^{\circ} 01.247^{\prime} \mathrm{E} 15^{\circ} 35.707^{\prime}$ & 70 & 1 & \\
\hline 3 & $\mathrm{~N}^{\prime} 7^{\circ} 01.349^{\prime} \mathrm{E} 15^{\circ} 35.647^{\prime}$ & 92 & 1 & \\
\hline 4 & $\mathrm{~N}^{\prime} 7^{\circ} 01.358^{\prime} \mathrm{E} 15^{\circ} 35.641^{\prime}$ & 87 & 23 & 12 \\
\hline 5 & $\mathrm{~N} 77^{\circ} 01.378^{\prime} \mathrm{E} 15^{\circ} 35.702^{\prime}$ & 86 & & \\
\hline 6 & $\mathrm{~N}^{\prime} 7^{\circ} 01.377^{\prime} \mathrm{E} 15^{\circ} 35.707^{\prime}$ & 85 & 153 & 14 \\
\hline 7 & $\mathrm{~N} 77^{\circ} 01.417^{\prime} \mathrm{E} 15^{\circ} 35.956^{\prime}$ & 91 & 67 & 2 \\
\hline 8 & $\mathrm{~N} 77^{\circ} 01.464^{\prime} \mathrm{E} 15^{\circ} 36.254^{\prime}$ & 101 & 22 & 6 \\
\hline 9 & $\mathrm{~N}^{\prime} 7^{\circ} 01.302^{\prime} \mathrm{E} 15^{\circ} 35.716^{\prime}$ & 81 & 1 & 2 \\
\hline 10 & $\mathrm{~N}^{\prime} 7^{\circ} 01.302^{\prime} \mathrm{E} 15^{\circ} 35.716^{\prime}$ & 81 & 8 & \\
\hline
\end{tabular}

Tab. 2. List of cryoconite samples from Ebba Glacier (11-13), Hørbye Glacier (14-18), Nordenskiöld Glacier (19-28) with date of collection, GPS coordinates, elevation, number of individuals determined to species/genus level. For sampling sites localities see Figs. 1 and 2. The table presents faunistic analysis of randomly selected for slides tardigrades.

\begin{tabular}{|c|c|c|c|c|c|c|c|c|}
\hline $\mathbf{N}$ & Date & GPS & Elevation (m) & P. recamieri & H. dujardini & $\begin{array}{c}\text { Hypsibius } \\
\text { sp. A }\end{array}$ & $\begin{array}{c}\text { Isohypsibius } \\
\text { sp. A }\end{array}$ & $\begin{array}{c}\text { Undetermined } \\
\text { species of } \\
\text { Ramazzottiidae }\end{array}$ \\
\hline 11 & 8 August 2014 & N7843.823’ E16 $52.458^{\prime}$ & 306 & & & 1 & & \\
\hline 12 & 8 August 2014 & N7844.499’ E1654.630' & 525 & 2 & 1 & 2 & & \\
\hline 13 & 8 August 2014 & N7843.866’ E1651.268' & 286 & 4 & & & & 2 \\
\hline 14 & 21 July 2014 & N78 $45.421^{\prime} \mathrm{E} 16^{\circ} 19.516^{\prime}$ & 230 & 2 & 3 & 1 & 1 & \\
\hline 15 & 17 August 2014 & N78 $45.413^{\prime}$ E16 $19.487^{\prime}$ & 230 & 1 & 1 & & & \\
\hline 16 & 17 August 2014 & $\mathrm{~N} 78^{\circ} 45.412^{\prime} \mathrm{E} 16^{\circ} 19.498^{\circ}$ & 230 & 1 & & & & \\
\hline 17 & 14 August 2013 & N7845.414' E16º 19.473' & 190 & 1 & 3 & & & \\
\hline 18 & 14 August 2013 & N78 $45.413^{\prime}$ E $16^{\circ} 19.459^{\prime}$ & 203 & 2 & 6 & & & \\
\hline 19 & 31 July 2014 & N78³8.338' E16 $59.357^{\prime}$ & 150 & 2 & & & & \\
\hline 20 & 22 August 2014 & N78³8.339’ E1659.358' & 150 & 1 & & 1 & & \\
\hline 21 & 16 July 2014 & N78³8.325’ E16 59.484' & 150 & 2 & & & & \\
\hline 22 & 31 July 2014 & $\mathrm{~N} 78^{\circ} 38.288^{\prime} \mathrm{E} 16^{\circ} 59.450^{\prime}$ & 150 & 2 & 2 & & & \\
\hline 23 & 13 July 2014 & $\mathrm{~N} 78^{\circ} 39.103^{\prime} \mathrm{E} 17^{\circ} 03.306^{\prime}$ & 200 & & & & & \\
\hline 24 & 13 July 2014 & $\mathrm{~N} 78^{\circ} 39.250^{\prime} \mathrm{E} 17^{\circ} 03.744^{\prime}$ & 200 & & & & & \\
\hline 25 & 13 July 2014 & $\mathrm{~N} 78^{\circ} 38.892^{\prime} \mathrm{E} 17^{\circ} 02.521^{\prime}$ & 200 & & & & & \\
\hline 26 & 16 July 2014 & N78³9.103’ E17º3.393' & 200 & & & & & \\
\hline 27 & 22 July 2014 & N78 $39^{\prime} \mathrm{E} 17^{\circ} 03.4^{\prime}$ & 200 & & & & & \\
\hline 28 & 22 July 2014 & $\mathrm{~N} 78^{\circ} 39.2^{\prime} \mathrm{E} 17^{\circ} 03.4^{\prime}$ & 200 & & & & & \\
\hline
\end{tabular}

Tab. 3. List of cryoconite samples from Buchan Glacier (29-31) and Waldemar Glacier (32-33) with date of collection, GPS coordinates, elevation, and number of individuals determined to species/genus level. For sampling sites localities see Figs. 1 and 2.

\begin{tabular}{|c|c|c|c|c|c|c|c|}
\hline $\mathbf{N}$ & Date & GPS & Elevation (m) & P. recamieri & H. dujardini & Hypsibius sp. A & Isohypsibius sp. A \\
\hline 29 & 4 August 2013 & N79³4.764' E 116.019’ & 228 & 15 & & 26 & \\
\hline 30 & 4 August 2013 & $\mathrm{~N} 79^{\circ} 34.769^{\prime} \mathrm{E} 11^{\circ} 6.043^{\prime}$ & 230 & & & & \\
\hline 31 & 4 August 2013 & $\mathrm{~N} 79^{\circ} 34.778^{\prime} \mathrm{E} 11^{\circ} 6.1^{\prime}$ & 234 & 1 & 1 & 5 & 6 \\
\hline 32 & 28 July 2013 & $\mathrm{~N} 78^{\circ} 40.578^{\prime} \mathrm{E} 12^{\circ} 01.614^{\prime}$ & 195 & & 4 & 4 & 6 \\
\hline 33 & 28 July 2013 & $\mathrm{~N} 78^{\circ} 40.578^{\prime} \mathrm{E} 12^{\circ} 01.617^{\prime} 201$ & & & & 1 & 1 \\
\hline
\end{tabular}


the dark. After two weeks, physicochemical analysis was conducted in the chemical laboratories of the Hornsund Polish Polar Station (Spitsbergen). Conductivity and $\mathrm{pH}$ were measured with an Elmetron CX-505 and glass electrodes. Water samples were filtered in a vacuum by a Millipore filtration kit with rinsed Whatmann nylon filters $(0.22 \mu \mathrm{m})$. Subsequent water samples were analysed for their chemical composition, including $\mathrm{SO}_{4}^{-2}, \mathrm{Cl}^{-}, \mathrm{NO}_{2}^{-}$, $\mathrm{NO}_{3}{ }^{-}, \mathrm{F}^{-}, \mathrm{Br}^{-}, \mathrm{Ca}^{2+}, \mathrm{Mg}^{+2}, \mathrm{Na}^{+}, \mathrm{K}^{+}$, and $\mathrm{NH}_{4}^{+}$. Anions and cations were determined by high performance liquid chromatography (HPLC) through two separate Metrohm 761 Compact IC Systems. Alkalinity was determined by the titration method (Metrohm 702 SM Titrino) (Stachnik et al., 2016). The quality of analyses were determine by charge balance error for each sample: $1.4 \%$ (sample 29); $22 \%$ (sample 30 ), and $3.3 \%$ (sample 31 ). Ion balance criteria met the standards of UNEP and WMO (Bartram and Balance, 1996; Allan, 2015). Samples from the Buchan Glacier were replicated, three samples were collected for tardigrade fauna analysis and three from the same cryoconite holes for chemical analysis. As only three samples were collected, statistical analysis are omitted and remarks on the links between tardigrade and chemistry are presented in the 'Discussion' section.

Chemical analysis on the cryoconite holes on Dickson Land glaciers were conducted by Vonnahme et al. (2015). However, concentration of all analytes are given in $\mathrm{mmol} / \mathrm{kg}$ what makes unreasonable the comparison of these values with our results. Thus, we decided to omit this comparison in Tab. 4.

\section{RESULTS}

Tardigrades were found in 25 samples. In those samples, specimens belonging to five tardigrade taxa were discovered. They represent 2 superfamilies, 4 families and 4 genera, being Hypsibius dujardini, Hypsibius sp. A, Isohypsibius sp. A, Pilatobius recamieri, and one undetermined species of Ramazzottiidae (for taxonomic and zoogeographic remarks, see Taxonomic Account). Data for samples with sample number, coordinates, altitude above sea level, are presented in Tabs. 1, 2 and 3. All sampling sites are detailed in Fig. 2. Pilatobius recamieri was the most frequent species, present in $22(88 \%)$ samples. Except for the undetermined species of Ramazzottiidae that was found on one glacier only, other species more frequently inhabited cryoconite holes. Tardigrades reported from Buchan Glacier are northernmost record of tardigrades from cryoconite holes. Densities of the tardigrades from Hans Glacier and glaciers in Billefjorden presented in this paper, in terms of cryoconite hole area, depth and elevation are covered in Zawierucha et al. (2016b).

Chemical determined $\mathrm{pH}$ values were in the range 6.50-7.45. Mean concentrations of cations, such as $\mathrm{Ca}^{2+}$,

Tab. 4. Mean values of physicochemical parameters/analytes determined in cryoconites samples collected from Buchan Glacier and results of the research performed by Porazińska et al. (2004) on glaciers in Antarctica.

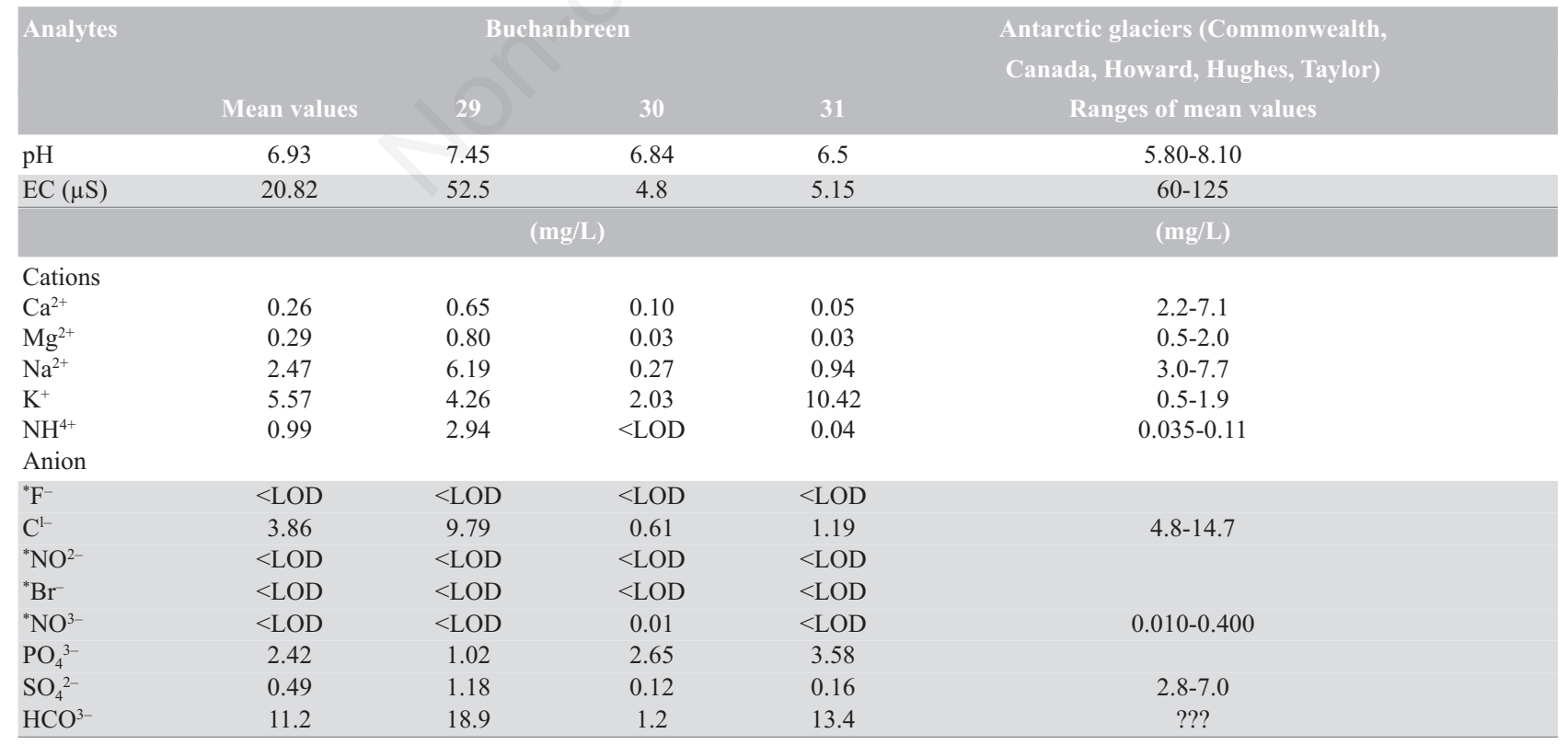

${ }^{*}<L O D$ - below limit of detection for $\mathrm{F}^{-}, \mathrm{NO}^{2-}, \mathrm{Br}, \mathrm{NO} \mathrm{O}^{3-}=0.010 \mathrm{mg} / \mathrm{L} ; \mathrm{LOQ}=0.030 \mathrm{mg} / \mathrm{L}$. Both the limit of detection (LOD) and the limit of quantitation $(L O Q)$ were calculated based on the standard deviation of the response (s) and the slope of the calibration curve (b) according to the formulas: $L O D=3.3$ $(s / b), L O Q=10(s / b)$. 
$\mathrm{Mg}^{2+}$, and $\mathrm{NH}_{4}^{+}$, did not exceed $1 \mathrm{mg} \mathrm{L}^{-1}$, while the mean concentrations of $\mathrm{Na}^{2+}$ and $\mathrm{K}^{+}$were, respectively, $2.47 \mathrm{mg}$ $\mathrm{L}^{-1}$ and $5.57 \mathrm{mg} \mathrm{L}^{-1}$. In the case of mean concentrations of anions in the examined samples, $\mathrm{HCO}_{3}^{-}, \mathrm{Cl}^{-}, \mathrm{PO}_{4}{ }^{3-}$ and $\mathrm{SO}_{4}{ }^{3-}$ were, respectively, $11.2 \mathrm{mg} \mathrm{L}^{-1}, 3.86 \mathrm{mg} \mathrm{L}^{-1}, 2.42$ $\mathrm{mg} \mathrm{L}^{-1}$, and $0.486 \mathrm{mg} \mathrm{L}^{-1}$, whereas no presence of $\mathrm{F}^{-}, \mathrm{Br}^{-}$, $\mathrm{NO}_{2}^{-}, \mathrm{NO}_{3}^{-}$, or $\mathrm{Br}^{-}$was observed (Tab. 4).

\section{Taxonomic account}

Phylum Tardigrada (Spallanzani, 1777)

Class Eutardigrada Richters, 1926

Order Parachela Schuster, Nelson, Grigarick et Christenberry, 1980

Superfamily Hypsibioidea Pilato, 1969 in Marley et al. (2011)

Family Hypsibiidae Pilato, 1969

Subfamily Hypsibiinae Pilato, 1969

Genus Hypsibius Ehrenberg, 1848

1. Hypsibius dujardini (Doyère, 1840) (Fig. $3 \mathrm{~A}-\mathrm{B}$ )

Localities: 12, 14, 15, 17, 18, 22, 31, 32.

Remarks: Species belongs to the cosmopolitan convergens-dujardini complex (McInnes, 1994; Miller et al., 2005; Kaczmarek and Michalczyk, 2009). The original description is inadequate and incomplete in the context of modern taxonomy methods, and so the examined specimens were compared with the later descriptions (Ramazzotti and Maucci, 1983; Dastych, 1988). This species is characterized by claws of Hypsibius type, two macroplacoids, septulum, and a short cuticular bar between claws IV. The species was previously reported from the Svalbard archipelago (Zawierucha et al., 2013).

2. Hypsibius sp. A (Fig. 4 A-E)

Localities: 1, 4, 6, 7, 8, 9, 11, 12, 14, 20, 29, 31, 32, 33.

Diagnosis: The body transparent/white, with eyes present in the examined specimens. The cuticle smooth in the PCM (Fig. 4A). The buccal apparatus of the Hypsibius type without ventral lamina (Fig. 4B). Peribuccal lamellae absent. Oral cavity armature either absent or not visible in the PCM (Fig. 4B). The pharyngeal bulb with apophyses, with two rod-shaped macroplacoids, second in lateral position broader at the end (Fig. 4C). The macroplacoid length sequence $2<1$, microplacoid and septulum absent. Stylet supports located in the posterior position. Typically shaped stylet furcae present. The apophyses clearly separated from the $1^{\text {st }}$ macroplacoids. All macroplacoids clearly separated (Fig. 4 B,C). Their usual claws of the Hypsibius type but with variation within even single specimens claws of the Isohypsibius type or the Mixibius type (Fig. 4 D, E). All main branches with accessory points (Fig. 4 D,E). Cuticular bars or thickening under and between the claws absent. Proper lunulae absent.

Remarks. This species belongs to a large group of hypsibids with two macroplacoids and a smooth cuticle. It was previously found in cryoconite holes on Spitsbergen (Dastych, 1985). Dastych (1985) had previously reported Hypsibius ? arcticus from cryoconite holes on Spitsbergen. However, that determination was uncertain because of the absence of eggs in the samples (Dastych, 1985). The current findings are evidence that Hypsibius sp. A (noted by Dastych (1985) as Hypsibius ? arcticus) laid eggs to exuvia, thus, it is not Hypsibius arcticus (Murray, 1907). This species, by presence of smooth cuticle, two macroplacoids, and the macroplacoid length sequence, is the most similar to $H$. arcticus, and $H$. convergens (Urbanowicz, 1925), known before from non-glacial habitats (Ramazzotti and Maucci, 1983). Up to now, tardigrades recorded from the Arctic tundra were not morphologically the same as Hypsibius sp. A. However, erection of the Hypsibius sp. A to the new species without redescriptions of the other hypsibids (Kaczmarek et al., 2015) made exact differential diagnosis difficult. To avoid taxonomic confusion, if additional new fresh material will available together with individuals for exact comparison, Hypsibius $\mathrm{sp}$. A will be described together with morphometric data in a future paper.
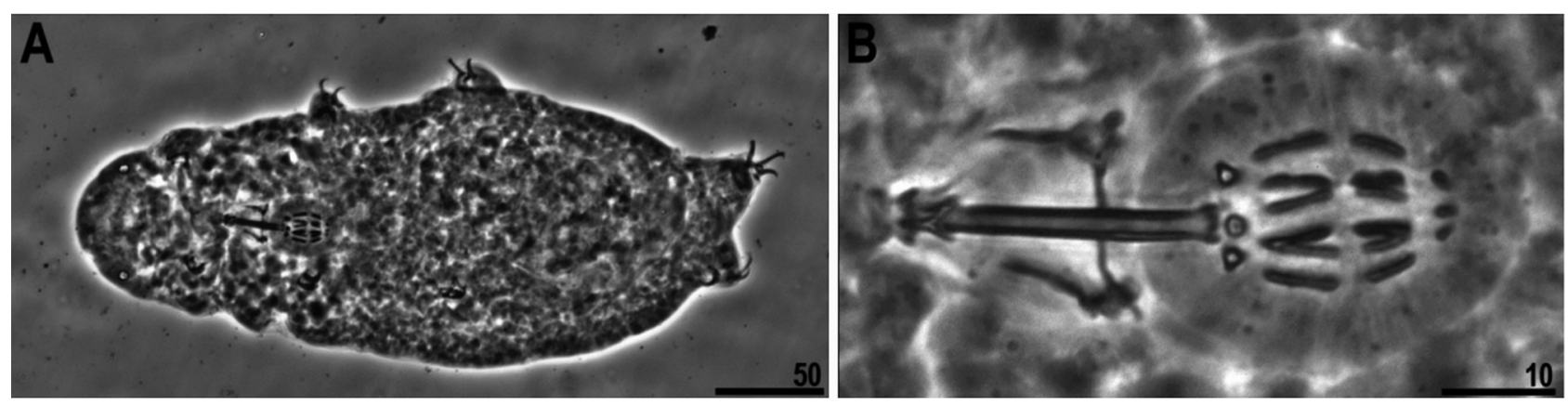

Fig. 3. Hypsibius dujardini. A) Habitus. B) Buccal apparatus. 
Family Pilatobiinae Bertolani, Guidetti, Marchioro, Altiero, Rebecchi \& Cesari, 2014

Genus Pilatobius Bertolani, Guidetti, Marchioro, Altiero, Rebecchi \& Cesari, 2014

\section{Pilatobius recamieri Richters, 1911 (Fig. 5 A-B)}

Localities: 1, 2, 3, 4, 6, 7, 8, 9, 10, 12, 13, 14, 15, 16, 17, $18,19,20,21,22,29,31$.

Remarks: Holarctic species, recorded from localities in Europe, Asia and North America (McInnes, 1994). Previously reported from Svalbard archipelago (Zawierucha et al., 2013). It comes from cryoconite holes reported from Spitsbergen, Greenland and Norway (Zawierucha et al., 2015a).
4. Family Ramazzottiidae Sands, McInnes, Marley, Goodall-Copestake, Convey \& Linse, 2008

Locality: 13 .

Diagnosis: Black pigmented cuticle present (Fig. 6A). Peribuccal lamellae absent. The oral cavity armature absent or not visible in the PCM. The pharyngeal bulb with apophyses, with two rod-shaped macroplacoids, the first with constriction. The macroplacoid length sequence $2<1$, and the microplacoid and septulum absent (Fig. 6B). Stylet supports were located in the posterior position. Typical stylet furcae present. The apophyses clearly separated from the $1^{\text {st }}$ macroplacoids. All macroplacoids are clearly separated (Fig. 6B). Claws of Ramazzottius type with
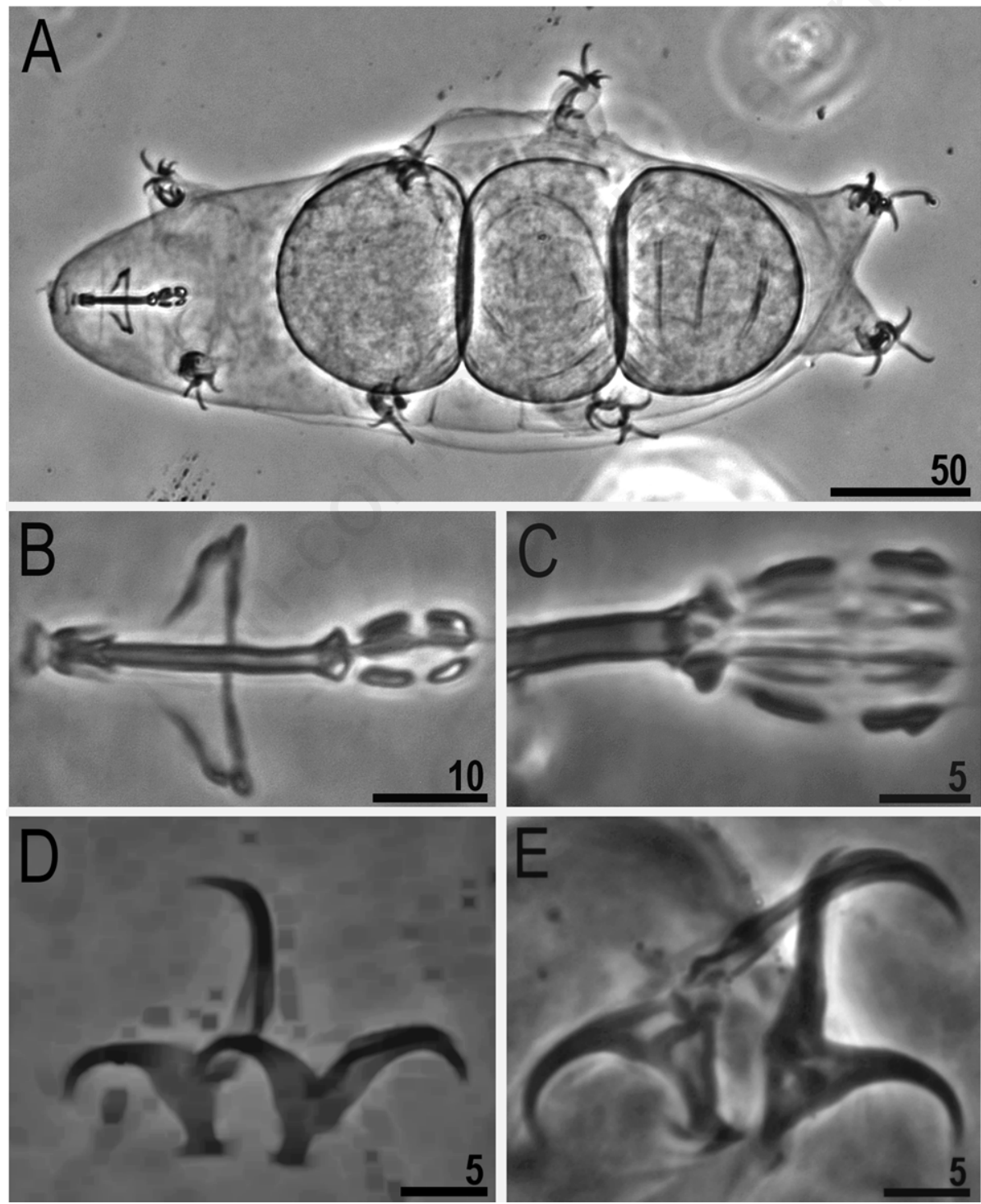

Fig. 4. Hypsibius sp. A. A) Habitus in moulting state. B) Buccal apparatus. C) Macroplacoids in lateral position. D) Claws III. E) Claws IV. 
strongly thin main branches of external claws. All branches without accessory points (Fig. 6C). Cuticular bars or thickening under and between the claws absent or not visible in destroyed specimens preserved in formaldehyde and analysed under PCM. Proper lunules absent or not visible in destroyed specimens preserved in formaldehyde and analyzed under PCM.

Remarks: Only two black pigmented individuals collected from the Ebba Glacier have been analysed. Individuals were destroyed because of long preservation in formaldehyde. Proper delimitation at the genus level was difficult. The generic feature, the apophyses for the insertion of the stylet muscles, are completely invisible. The claws are of Ramazzottius type but with a rare feature - a lack of accessory points. Despite the fact that they were conserved in formaldehyde and then prepared in Hoyer medium, they did not lose the dark pigment in the cuticle. Other glacier tardigrades in the Alps and Himalayas (Dastych et al., 2003; Dastych, 2004) were noted to have black pigment that protected them from high doses of UV radiation (Greven et al., 2005). Strong black pigmentation of the examined individuals may be a unique adaptation to glacier environment. Without more individuals preserved in better condition, with suitable character for proper morphological and morphometric analysis, discussion on the status of this species is unfounded. Morphologically similar specimens have been found in cryoconites in Tien and the Quilian Mountains (personal observation). Based on problems with proper identification at the genus level, we decided to delimit individuals at the family level.

Superfamily Isohypsibioidea Sands, McInnes, Marley, Goodall-Copestake, Convey \& Linse, 2008

Family Isohypsibiidae Sands, McInnes, Marley, GoodallCopestake, Convey \& Linse, 2008

Genus Isohypsibius Thulin, 1928

\section{Isohypsibius sp. A (Fig. 7 A-C)}

Localities: 14, 31, 32, 33.

Diagnosis: The body transparent/white, with eyes present in the examined specimens. The cuticle smooth in the PCM (Fig. 7A). The buccal apparatus of the Isohypsibius type without ventral lamina (Fig. 7B). Peribuccal lamellae absent. The oral cavity armature comprised of a single ventral and dorsal band of small round teeth in the posterior portion of the oral cavity (barely visible in certain specimens). The pharyngeal bulb with apophyses, with three rod-shaped macroplacoids, all without constrictions. Macroplacoid length sequence $1<2<3$ and microplacoid and septulum absent (Fig. 7B). Stylet supports located in the posterior position. Typically, stylet furcae present. The apophyses clearly separated from the $1^{\text {st }}$ macroplacoid. All macroplacoids were clearly separated. Claws of the Isohypsibius type (Fig. 7C). All external and all internal claws similar in shape and all main branches with accessory points. Short, cuticular bars present on legs I-III
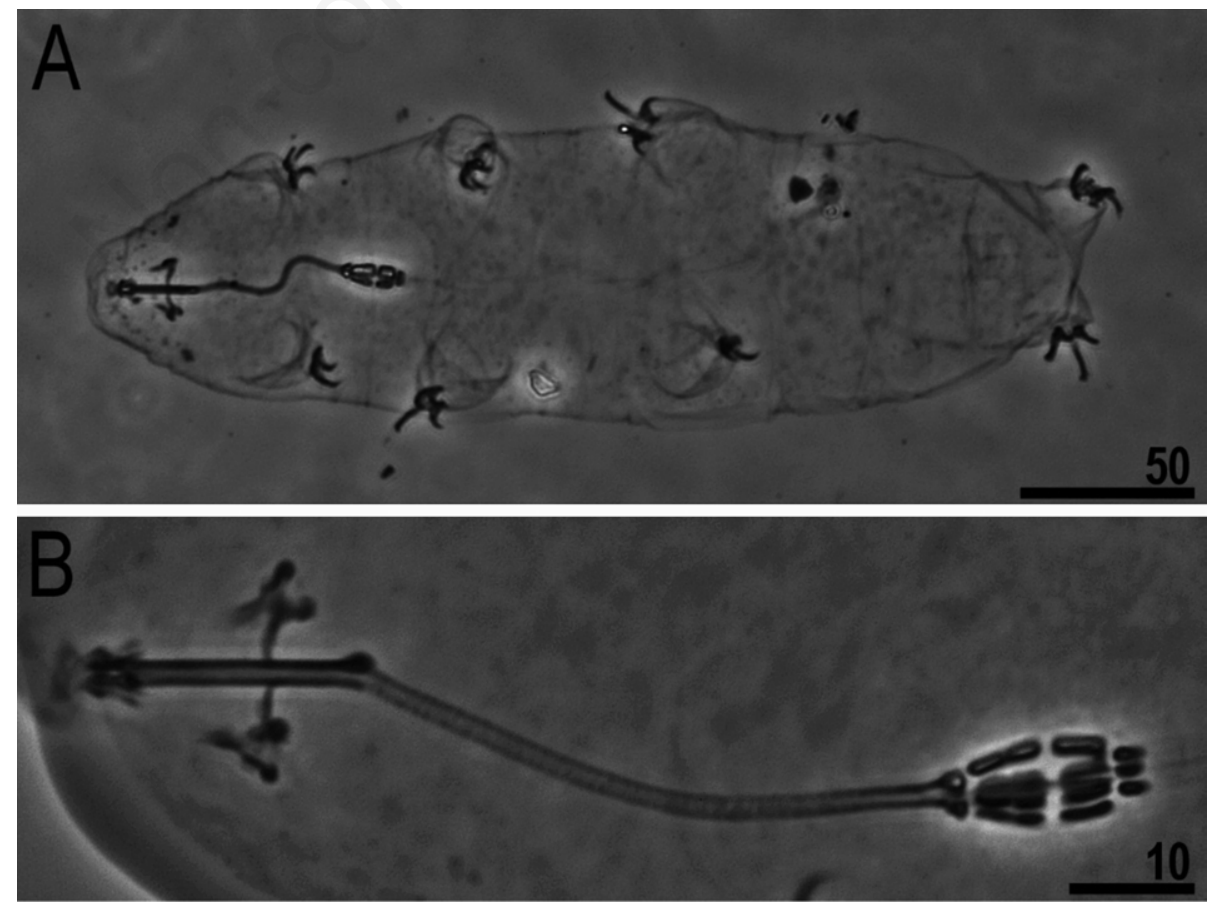

Fig. 5. Pilatobius recamieri. A) Habitus. B) Bucco-pharyngeal apparatus. 
(sometimes poorly visible). Other cuticular structures or thickening between claws absent. Proper lunules absent, and only certain areoles visible under the claw bases but needed clarification in better preserved individuals. Eggs smooth and deposited in exuvia.

Remarks: This species belongs to a large group of isohypsibids with three macroplacoids, smooth cuticle and cuticular bars. This species, based on the presence of smooth cuticle, three macroplacoids, and macroplacoid length sequence is the most similar to I. tetradactyloides (Richters, 1907) and I. schaudinni (Richters, 1909), known before from non-glacial habitats (Ramazzotti and Maucci, 1983). Up to now, tardigrades recorded from the Arctic tundra were not morphologically the same as Isohypsibius sp. A. However, erection of the Isohypsibius sp. A, to the new species without redescriptions of other isohypsibids (e.g., I. schaudinni, I. tetradactyloides; Kaczmarek et al., 2015) made precise differential diagnosis difficult. More- over, more well-preserved material for morphometry and confirmation of presence/absence of lunules is required. To avoid taxonomic confusion, if additional new fresh material will be available together with individuals for exact comparison, Isohypsibius sp. A will be described together with morphometric data in a future paper.

\section{DISCUSSION}

\section{Tardigrada diversity and distribution}

In this study, five tardigrade taxa in cryoconite holes sediment were discovered and are presented as the first comprehensive data regarding their distribution on glaciers in Spitsbergen. Current data from Spitsbergen, along with previous surveys, clearly indicates that tardigrade diversity in cryoconite holes is low in comparison to Arctic terrestrial ecosystems in which up to 10 species per moss sample may be found (Dastych, 1985). However, some species are
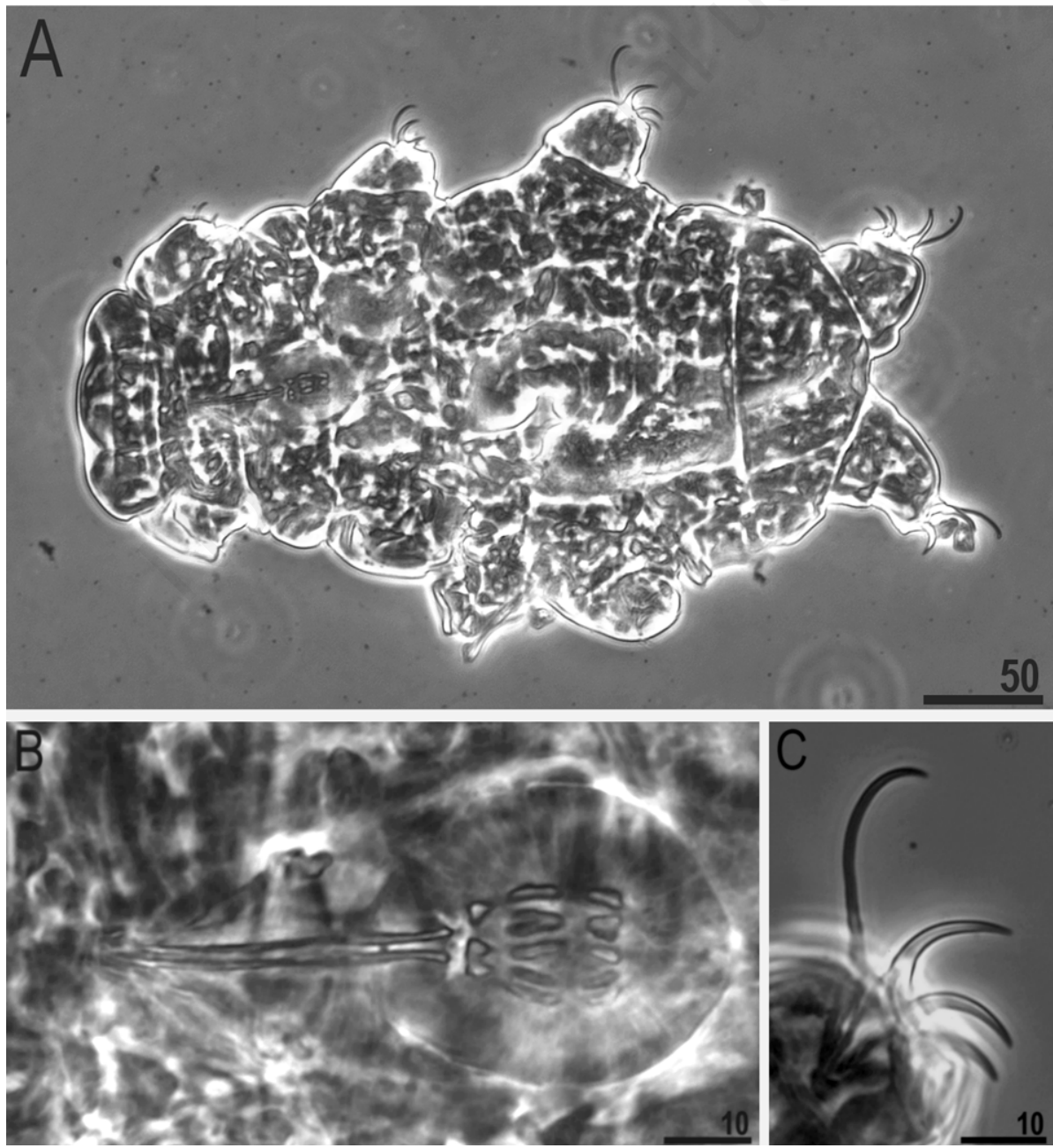

Fig. 6. Undetermined species of Ramazzottiidae. A) Habitus. B) Buccal apparatus. C) Claws III. 
unique to this environment and known only from glaciers, like Hypsibius sp. A, Isohypsibius sp. A, found in this study, or other tardigrades in the Alps e.g., Hypsibius klebelsbergi Mihelčič, 1959 or Himalayas, H. janetscheki Ramazzotti, 1968 and H. thaleri Dastych, 2004.

In recent papers published by Kaczmarek et al. (2012) and Zawierucha et al. (2013, 2015b, 2016a), mosses, lichens, soil, and mixed samples (moss/lichen) were analysed and observed such that previously recorded species were not morphologically similar to Hypsibius sp. A, species of Ramazzottiidae and Isohypsibius sp. A from cryoconite holes (all collected samples and specimens are deposited at the Department of Animal Taxonomy and Ecology, Adam Mickiewicz University in Poznań). Dastych (1985) found Hypsibius sp. A only in cryoconite samples and noted it as Hypsibius ? arcticus (see 'Remarks' for details). The picture was included in that work (Plate VII) with buccal apparatus of this species. We also found Hypsibius sp. A exclusively in cryoconite holes, the buccal apparatus is the same and it is also similar to Hypsibius arcticus. That is why we are certain that it is the same species as in the work of Dastych (1985). Moreover, Dastych (1991) questioned the determination of Hypsibius arcticus and discussed validation. Dastych (1985) did not find Isohypsibius sp. A and species of Ramazzottiidae in cryoconite holes. Isohypsibius sp. A, Hypsibius sp. A and $P$. recamieri were discovered by Grøngaard et al. (1999) in the Greenland ice caps and deposited at ZMUC. Material from the present study was compared with specimens deposited at ZMUC, and Isohypsibius sp. A, Hypsibius sp. A and P. recamieri are morphologically identical (KZ personal observation). Taking in to consideration i) the huge sample size of terrestrial material analysed so far and the absence of species found in cryoconite holes, as well as this being ii) the same species found in Greenland cryoconite holes, Isohypsibius sp. A and Hypsibius sp. A may be deemed unique glacier inhabitants.

Only Dastych (1985) and De Smet and Van Rompu (1994) conducted studies on the glacier tardigrades in Svalbard. They investigated three glaciers (Sörbreen, Tryggvebreen, Hyrnebreen) and their found four species: H. dujardini, Hypsibius sp. A, P. recamieri and Isohypsibius granulifer granulifer (Thulin, 1928), with the most frequent $P$. recamieri (Dastych, 1985; De Smet and Van Rompu, 1994). Knowledge on the glacier tardigrades from Svalbard archipelago include totally nine glaciers
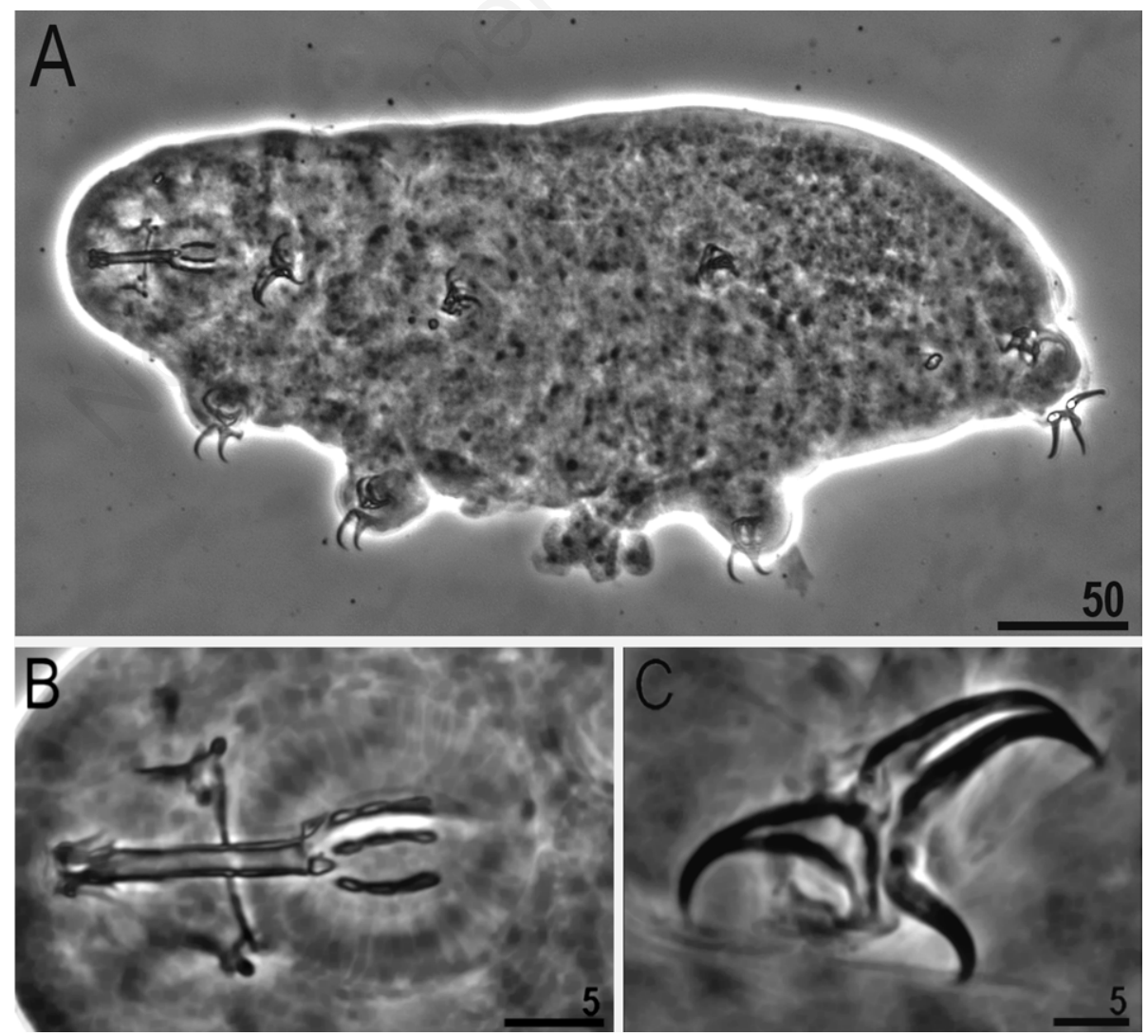

Fig. 7. Isohypsibius sp. A. A) Habitus; B) Buccal apparatus; C) Claws I. 
(six analysed in this study and three in previous). Distribution of tardigrades seems to be homogenous - with the most dominant species P. recamieri, then Hypsibius sp. A, $H$ dujardini and less frequent Isohypsibius sp. A. Up to now, undetermined species of Ramazzottidae and $I . g$. granulifer are known only from single glaciers.

\section{Biochemistry}

Porazińska et al. (2004) discussed the relationship between invertebrates (rotifers and tardigrades) inhabiting Antarctic cryoconites and the chemistry of the environment in which they live. Authors suggest that higher $\mathrm{pH}$ and lower $\mathrm{NO}^{3-}$ concentration favour higher densities of tardigrades in cryoconite sediments (Porazińska et al., 2004). These parameters determined in the Buchan Glacier samples were in the following ranges: 6.5-7.45 (pH) and $\mathrm{NO}_{3}^{-}<$LOD (limit of detection), indicating favourable conditions for life and development of tardigrades. It is also stated that tardigrade variation may be explained by the concentration of primary macronutrients $\left(\mathrm{NH}_{4}{ }^{+}\right.$and $\left.\mathrm{NO}_{3}-\right)$ as well as secondary macronutrients $\left(\mathrm{Mg}^{2+}\right)$ (Porazińska et al., 2004). Ammonium present in samples collected from the Buchan glacier was on the order of magnitude $<\mathrm{LOD}$ of $2.94 \mathrm{mg} \mathrm{L}^{-1}$. The mean value of $\mathrm{NH}_{4}^{+}$was about nine times greater than the highest value detected by Porazińska et al. (2004) in Antarctic glacier samples (Table 4). Cryoconite holes with the highest concentrations of $\mathrm{NH}_{4}{ }^{+}$were also characterized by the highest levels of magnesium $(0.800$ $\mathrm{mg} \mathrm{dm}{ }^{-3}$ ). Occurrence of tardigrades seems to be related to concentrations of $\mathrm{Mg}^{2+}$ and other cations, including $\mathrm{K}^{+}$and $\mathrm{Ca}^{2+}$.

The highest conductivity, and highest concentration of the most of ions can be found in sample 29, which was located lower (228 $\mathrm{m}$ asl) than the two other samples (230 and $234 \mathrm{~m}$ asl; Tab. 4). Differences in chemical composition can be because of i) the shorter distance to the sea and influence of the sea aerosols; or ii) the result of the flow of matter through water flow on the Buchan Glacier surface.

\section{Glacial biome - unique species and food web}

This study presents evidence for the biotic background of a glacial biome hypothesis. Firstly, despite the extreme conditions of ice environments, organisms were found in most of samples. Thus, they cannot be fortuitous elements on glaciers and certainly have adaptations and strategies like other glacier inhabitants (Price, 2000; Zawierucha et al., 2015a; Singh et al., 2014). Secondly, the presence of different trophic groups (herbivores, microbivores, and higher-level consumers) is not possible without the presence of autotrophs, which commonly inhabit glaciers (Kaczmarek et al., 2016). Therefore, glacial ecosystems on Spitsbergen are typified by truncated food webs. This is supported by other environmental studies conducted on Svalbard glaciers (Vonnahme et al., 2015). Finally, a strong selection pressure resulting from extreme conditions on the ice influences the unique character of organisms inhabiting glaciers (species which were found strictly in cryoconite holes). Similar to cryoconite holes, ephemeral micro-ecosystems are formed in the axils of Bromeliaceae, where species specialists but also species known for their wide tolerance of habitats have been discovered. It seems that a number of the species living in them are endemic, while others cosmopolitan or they constitute complexes of morphologically similar taxa or cryptic species (Balke et al., 2008; Kolicka 2016; Kolicka et al., 2016). Observations on the species in bromeliads are analogous to those in cryoconite holes - there is a wide distribution of $P$. recamieri and a limited distribution within cryoconite holes of e.g., Isohypsibius sp. A.

Vonnahme et al. (2015) showed that grazing by tardigrades has a positive influence on eukaryotic microalgae by nutrient recycling in cryoconite holes. Similar observations on the trophic web at the microscale have been demonstrated on decaying caribou antlers in the Arctic (Sutcliffe and Blake, 2000). In these unusual ecosystems, mosses, lichens and algae are photoautotrophic producers and tardigrades (with mites and dipterans) are primary consumers (Sutcliffe and Blake, 2000). Trophic webs in Bromeliad tanks also present analogies to cryoconite holes. However, grazers are less abundant, and more fortuitous species can be observed in bromeliads (Brouard et al., 2011; Kolicka et al., 2016).

\section{CONCLUSIONS}

Despite extreme conditions and high ice melt, tardigrades can inhabit cryoconite sediments in high densities (Zawierucha et al., 2016b). Glacier organisms may influence the size of cryoconite holes (McIntyre, 1984). Therefore, the presence or absence of invertebrates (which are considerably larger than bacteria, viruses or algae), could affect the melting of glacier surfaces and should be discussed in future literature as a part of bicryomorphological studies (Zawierucha et al., 2015a; Cook et al., 2015). The presence of unique cryoconite tardigrade species indicate cryoconites as distinctive extreme habitats and tardigrades as a constant element in a glacial biome, with different communities structure than in tundra. Most likely, tardigrades adapted to life on a glacier rather than being transported there by accident as hypothesized earlier by Grøngaard et al. (1999). The important role of tardigrades in a trophic web (the herbivorous genus, Hypsibius, or the microbivore genus, Pilatobius), greatly corroborates the hypothesis of a multitrophic food web in cryoconites. Various tardigrade species may recycle limiting nutrients to microalgae and bacteria, and compete with or suppress bacterivorous and grazing rotifers and ciliates. 


\section{ACKNOWLEDGMENTS}

Special thanks go to Mr. Wojciech Mateja from XXXVII Polish Polar Expedition to Hornsund Polish Polar Station for kindly helping and supporting during sample collection on the Hans Glacier and chemical analysis. We are grateful to Diego Fontaneto for valuable remarks that improved manuscript. We also grateful to two anonymous reviewers for their comments on manuscript. K.Z. wants to thank Professor R.M. Kristensen for permitting and the possibility of analysing material of cryoconites from Greenland; visiting at ZMUC was funded by SYNTHESYS Project http://www. synthesys.info/, which is financed by European Community Research Infrastructure Action under the FP7 (DKTAF-2706). K.Z. also wants to thanks to PhD Łukasz Kaczmarek and PhD Łukasz Michalczyk for consultations. Text was proofread by Cambridge Proofreading Worldwide LLCB. Studies were supported by a National Science Centre, grant no. NCN 2013/11/N/NZ8/00597 for K.Z., and partially by the European Social Fund and state budget of the Czech Republic, no. CZ.1.07/ 2.2.00/28.0190. Sampling were conducted by K.Z. (2013) under permits RIS number 6390. K.Z. is a beneficiary of National Science Center scholarship for $\mathrm{PhD}$ No. 2015/ 16/T/NZ8/00017.

\section{REFERENCES}

ACIA, 2006. Arctic Climate Impact Assessment. Scientific Report. Cambridge University Press, Cambridge: 1042 pp.

Anesio AM, Laybourn-Parry J, 2012. Glaciers and ice sheets as a biome. Trends Ecol. Evol. 4:219-225.

Allan MA, 2015. Manual for the GAW precipitation chemistry programme. Guidelines, Data Quality Objectives and Standard Operating Procedures. World Meteorological Organization, Global Atmosphere Watch. No. 160: 170 pp.

Bagshaw EA, Tranter M, Wadham JL, Fountain AG, Dubnick A, Fitzsimons S, 2016a. Processes controlling carbon cycling in Antarctic glacier surface ecosystems. Geochem. Persp. Let. 2:44-54.

Bagshaw EA, Wadham JL, Tranter M, Perkins R, Morgan A, Williamson CJ, Fountain AG, Fitzsimons S, Dubnick A, 2016b. Response of Antarctic cryoconite microbial communities to light. FEMS Microbiol. Ecol. DOI: http://dx.doi. org/10.1093/ femsec/fiw076.

Balke M, Gomez-Zurita J, Ribera I, Viloria A, Zillikens A, Steiner J, Garcia M, Hendrich L, Vogler AP, 2008. Ancient associations of aquatic beetles and tank bromeliads in the Neotropical forest canopy. Proc. Natl. Acad. Sci. USA 105: 6356-6361.

Bartram J, Balance R, 1996. Water Quality Monitoring. A practical guide to the design and implementation of freshwater quality studies and monitoring programmes. Water Quality Assessments. UN Environment Programme. E \& FN SPON: $366 \mathrm{pp}$.

Bertolani R, Guidetti R, Marchioro T, Altiero T, Rebecchi L, Cesari M, 2014. Phylogeny of Eutardigrada: New molecular data and their morphological support lead to the identification of new evolutionary lineages. Mol. Phylogenet. Evol. 76:110-126.

Brouard O, Le Jeune AH, Leroy C, Cereghino R, Roux O, Pelozuelo L, Dejean A, Corbara B, Carrias JF, 2011. Are Algae Relevant to the Detritus-Based Food Web in TankBromeliads? PLoS One 6:e20129.

Callaghan TV, Tweedie CE, 2011. Multi-decadal changes in tundra environments and ecosystems: the International Polar Year - back to the future project. Ambio 40:555-716.

Cook JM, Edwards A, Bulling M, Mur LAJ, Cook S, Gokul JK, Cameron KA, Sweet M, Irvine-Fynn TDL, 2016a. Metabolome-mediated biocryomorphic evolution promotes carbon fixation in Greenlandic cryoconite holes. Environ. Microbiol. DOI: 10.1111/1462-2920.13349 [Epub ahead of print].

Cook J, Edwards A, Hubbard A, 2015. Biocryomorphology: integrating microbial processes with ice surface hydrology, topography, and roughness. Front. Earth. Sci. 3:78.

Cook J, Edwards A, Takeuchi N, Irvine-Fynn T, 2016b. Cryoconite. The dark biological secret of the cryosphere. Prog. Phys. Geogr. 1-46.

Coulson SJ, Convey P, Aakra K, Aarvik L, Ávila-Jiménez ML, Babenko A, Biersma EM, Boström S, Brittain JE, Carlsson AM, Christoffersen K, De Smet WH, Ekremj T, Fjellberg A, Füreder L, Gustafssonm D, Gwiazdowicz DJ, Hansen LO, Holmstrup M, Hullé M, Kaczmarek Ł, Kolicka M, Kuklin V, Lakka HK, Lebedeva N, Makarova O, Maraldo K, Melekhina E, Ødegaard F, Pilskog HE, Simon JC, Sohlenius B, Solhøy T, Søli G, Stur E, Tanasevitch A, Taskaeva A, Velle G, Zawierucha K, Zmudczyńska-Skarbek K, 2014. The terrestrial and freshwater invertebrate biodiversity of the archipelagoes of the Barents Sea; Svalbard, Franz Josef Land and Novaya Zemlya. Soil Biol. Biochem. 68:440-470.

Dabert M, Dastych H, Dabert J, 2015. Molecular data support the dispersal ability of the glacier tardigrade Hypsibius klebelsbergi Mihelčič, 1959 across the environmental barrier (Tardigrada). Mitt. Hamb. zool. Mus. Inst. 17:233-240.

Dastych H, 1985. West Spitsbergen Tardigrada. Acta. Zool. Crac. 28:169-214.

Dastych H, 1988. The tardigrada of Poland. Mon. Faun. Pol. $16: 1-255$.

Dastych H, 1991. Redescription of Hypsibius antarcticus (Richters, 1904), with some notes on Hypsibius arcticus (Murray, 1907) (Tardigrada). Mitt. Hamb. zool. Mus. Inst. 88:141-159.

Dastych H, 2004. Hypsibius thaleri sp. nov., a new species of a glacier-dwelling tardigrade from the Himalayas, Nepal (Tardigrada). Mitt. hamb. zool. Mus. Inst. 101:169-183.

Dastych H, Kraus HJ, Thaler K, 2003. Redescription and notes on the biology of the glacier tardigrade Hypsibius klebelsbergi Mihelcic, 1959 (Tardigrada), based on material from Ötztal Alps, Austria. Mitt. Hamb. zool. Mus. Inst. 100:73-100.

Degma P, Bertolani R, Guidetti R, 2011. Actual checklist of Tardigrada species (2009-2011, Ver. 19:31-05-2011). Available from: http://www.tardigrada.modena.unimo.it/ miscellanea/ Actual\%20checklist\%20of\%20Tardigrada.pdf

De Smet WH, Van Rompu EA, Beyens L, 1987. Contribution to the rotifers and aquatic Tardigrada of Edgeøya (Svalbard). Fauna Norv. Ser. A 9:19-30.

De Smet WH, Van Rompu EA, 1994. Rotifera and Tardigrada 
from some cryoconite holes on a Spitsbergen (Svalbard) glacier. Belg. J. Zool. 124: 27-37.

Edwards A, Anesio AM, Rassner SM, Sattler B, Hubbard B, Perkins WT, Young M, Griffith GW, 2011. Possible interactions between bacterial diversity, microbial activity and supraglacial hydrology of cryoconite holes in Svalbard. ISME J. 5:150-160.

Głowacki P, 2007. [Rola procesów fizyczno-chemicznych w kształtowaniu struktury wewnętrznej i obiegu masy lodowców Spitsbergenu].[Book in Polish]. Publications of the Institute of Geophysics Polish Academy of Sciences, Warszawa, vol. M-30, no. 400.

Greven H, Dastych H, Kraus HJ, 2005. Notes on the integument of the glacier-dwelling tardigrade Hypsibius klebelsbergi Mihelcic, 1959 (Tardigrada). Mitt. Hamb. zool. Mus. Inst. 102:11-20.

Grøngaard A, Pugh PJA, McInnes S, 1999. Tardigrades, and other cryoconite biota, on the Greenland ice sheet. Zool. Anz. 238:211-214.

Guil N, Sanchez-Moreno S, 2013. Fine-scale patterns in micrometazoans: tardigrade diversity, community composition and trophic dynamics in leaf litter. Syst. Biodivers. 11: 181-193.

Hagen JO, Liestol O, Roland E, Jorgensen T, 1993. Glacier atlas of Svalbard and Jan Mayen. Meddelelser, vol. 129. Norsk Polarinstitutt, Oslo.

Hagen JO, Kohler J, Melvold K, Winther JG, 2003. Glaciers in Svalbard: mass balance, runoff and freshwater flux. Pol. Res. 22:145-159.

Hjelle A, 1993. The geology of Svalbard. Oslo: Norwegian Polar Institute.

Hodson A, Anesio AM, Tranter M, Fountain A, Osborn M, Priscu J, Laybourn-Parry J, Sattler B, 2008. Glacial ecosystems. Ecol. Monogr. 78:41-67.

Kaczmarek Ł, Cytan J, Zawierucha K, Diduszko D, Michalczyk $Ł, 2014$. Tardigrades from Peru (South America), with descriptions of three new species of Parachela. Zootaxa 3790:357-379.

Kaczmarek Ł, Jakubowska N, Celewicz-Gołdyn S, Zawierucha K, 2016. Cryoconite holes microorganisms (algae, Archaea, bacteria, cyanobacteria, fungi, and Protista) - a review. Pol. Rec. 52:176-203.

Kaczmarek Ł, Michalczyk L, 2009. Redescription of Hypsibius microps Thulin, 1928 and H. pallidus Thulin, 1911 (Eutardigrada: Hypsibiidae) based on the type material from the Thulin collection. Zootaxa 2275:60-68.

Kaczmarek Ł, Michalczyk Ł, McInnes SJ, 2015. Annotated zoogeography of non-marine Tardigrada. Part II: South America. Zootaxa 3923:1-107.

Kaczmarek Ł, Zawierucha K, Smykla J, Michalczyk Ł, 2012. Tardigrada of the Revdalen (Spitsbergen) with the descriptions of two new species: Bryodelphax parvuspolaris (Heterotardigrada) and Isohypsibius coulsoni (Eutardigrada). Pol. Biol. 35:1013-1026.

Kiedrowicz A, Rector BG, Zawierucha K, Szydło W, Skoracka A, 2016. Phytophagous mites (Acari: Eriophyoidea) recorded from Svalbard, including the description of a new species. Pol. Biol. DOI:10.1007/s00300-015-1858-x

Kolicka M, 2016. Gastrotrichs in bromeliads - newly recorded Chaetonotus (Hystricochaetonotus) furcatus Kisielewski,
1991 (Chaetonotida) from the Lódź Palm House. Zoosystema 38:141-155.

Kolicka M, Gwiazdowicz DJ, Hupało K, Jabłońska A, Kotwicki L, Kornobis F, Lamentowicz M, Magowski W, Marcisz K, Pronin M, Reczuga MK, Olszanowski Z, Zawierucha K, 2016. Hidden invertebrate diversity - phytotelmata in Bromeliaceae from palm houses and florist wholesalers (Poland). Biologia 71:194-203.

Lonne I, Lysa A, 2005. Deglaciation dynamics following the Little Ice Age on Svalbard: Implications for shaping of landscapes at high latitudes. Geomorphol. 72:300-319.

Mangerud J, Svendsen JI, 1992. The last interglacial-glacial period on Spitsbergen, Svalbard. Quaternary Sci. Rev. 11: 633-664.

Małecki J, Faucherre S, Strzelecki M, 2013. Post-surge geometry and thermal structure of Horbyebreen, central Spitsbergen. Pol. Polar. Res. 34:305-321.

Marley NJ, McInnes SJ, Sands CJ, 2011. Phylum Tardigrada: a re-evaluation of the Parachela. Zootaxa 2819:51-64.

McIntyre NF, 1984. Cryoconite hole thermodynamics. Can. J. Earth. Sci. 21:152-156.

McInnes SJ, 1994. Zoogeographical distribution of terrestrial/ freshwater tardigrades from current literature. J. Nat. Hist. 28:257-352.

Miller WR, McInnes SJ, Bergstrøm DM, 2005. Tardigrades of the Australian Antarctic: Hypsibius heardensis (Eutardigrada: Hypsibiidae: dujardini group) a new species from sub-Antarctic Heard Island. Zootaxa 1022:57-64.

Morgan CI, 1975. Some notes on the Tardigrada of the Mullet peninsula, including four additios to the Irish fauna, and a key to the Irish species. Ir. Nat. J. 18:165-177.

Nelson DR, Guidetti R, Rebecchi L, 2015. Phylum Tardigrada, p. 347-380. In: J. Thorp and D.C. Rogers (eds.), Ecology and general biology: Thorp and Covich's freshwater invertebrates. Academic Press.

Owczarek P, Nawrot A, Migała K, Malik I, Korabiewski B, 2014. Floodplain responses to contemporary climate change in small High-Arctic basins (Svalbard, Norway). Boreas 43:384-402.

Porazińska DL, Fountain AG, Nylen TH, Tranter M, Virginia RA, Wall DH, 2004. The biodiversity and biogeochemistry of Cryoconite holes from McMurdo Dry Valley Glaciers, Antarctica. Arct. Antarct. Alp. Res. 36:84-91.

Przybylak R, Araźny A, 2005. [Porównanie warunków klimatycznych i bioklimatycznych północnej części Ziemi Oskara II z innymi obszarami zachodniego wybrzeża Spitsbergenu w okresie 1975-2000].[Article in Polish]. Prob. Klim. Pol. 15:119-131.

Przybylak R, Kejna M, Araźny A, 2011. Air temperature and precipitation changes in the Kaffiøyra region (NW Spitsbergen) from 1975 to 2010. Papers on Global Change 18:7-22.

Przybylak R, Araźny A, Nordli O, Finkelnburg R, Kejna M, Budzik T, Migała K, Sikora S, Puczko D, Rymer K, Rachlewicz G, 2014. Spatial distribution of air temperaturę on Svalbard during 1 year with campaign measurements. Int. J. Climatol. 34:3702-3719.

Price PB, 2000. A habitat for psychropiles in deep Antarctic ice. P. Natl. Acad. Sci. USA 97:1247-1251.

Purves WK, Sadava D, Orians GH, Heller HC, 2004. Life. The science of biology. W.H. Freeman, New York: 1121 pp. 
Rachlewicz G, 2009. Contemporary sediment fluxes and relief changes in high Arctic glacierized valley systems (Billefjorden, Central Spitsbergen). Seria geografia nr 87. Adam Mickiewicz University Press, Poznań: 203 pp.

Rachlewicz G, Styszyńska A, 2007.[Porównanie przebiegu temperatury powietrza w Petuniabukta i Svalbard-Lufthavn (Isfjord, Spitsbergen) w latach 2001-2003].[Article in Polish]. Probl. Klim. Polar 17:121-134.

Ramazzotti G, Maucci W, 1983. [Il Phylum Tardigrada].[Article in Italian]. Mem. Ist. Ital. Idrobiol. 41:1-1016.

Singh P, Singh SM, Dhakephalkar P, 2014. Diversity, cold active enzymes and adaptation strategies of bacteria inhabiting glacier cryoconite holes of High Arctic. Extremophiles 18:229-242.

Sobota I, 2009. The near-surface ice thermal structure of the Waldemarbreen, Svalbard. Pol. Pol. Res. 30:317-338.

Stachnik Ł, Majchrowska E, Yde JC, Nawrot AP, Cichała-Kamrowska K, Ignatiuk D, Piechota A, 2016. Chemical denudation and the role of sulfide oxidation at Werenskioldbreen, Svalbard. J. Hydrol. 538:177-193.

Sutcliffe AJ, Blake W Jr, 2000. Biological activity on a decaying caribou antler at Cape Herschel, Ellesmere Island, Nunavut, high Arctic Canada. Pol. Rec. 36:233-246.

Takeuchi N, Kohshima SS, Seko K, 2001. Structure, formation, and darkening process of albedo-reducing material (cryoconite) on a Himalayan glacier: a granular algal mat growing on the glacier. Arct. Antarct. Alp. Res. 33:115-122.

Vaughan DG, Comiso JC, Allison I, Carrasco J, Kaser G, Mote P, Murray T, Paul F, Ren J, Rignot E, Solomina O, Steffen K, Zhang T, 2013. Observations: Cryosphere. In: T.F. Stocker, D. Qin, G.K. Plattner, M. Tignor, S.K. Allen and J. Boschung (eds.), Contribution of working group I to the Fifth Assessment Report of the Intergovernmental Panel on
Climate Change. Cambridge University Press, Cambridge.

Vicente F, Bertolani R, 2013. Considerations on the taxonomy of the Phylum Tardigrada. Zootaxa 3626:245-248.

Vonnahme TR, Devetter M, Zárský JD, Sabacká M, Elster J, 2015. Controls on microalgal community structures in cryoconite holes upon high Arctic glaciers, Svalbard. Biogeosci. Discuss. 12:11751-11795.

Węglarska B, 1965. Die Tardigraden (Tardigrada) Spitzbergens. Acta Zool. Crac. 11:43-51.

Zawierucha K, 2013. Tardigrada from Arctic tundra (Svalbard, Spitsbergen) with a description of Isohypsibius karenae (Eutardigrada: Isohypsibiidae). Pol. Polar. Res. 34:383-396.

Zawierucha K, Coulson S, Michalczyk Ł, Kaczmarek Ł, 2013. Current knowledge of the Tardigrada of Svalbard with the first records of water bears from Nordaustlandet (High Arctic). Polar Res. 32:20886, http://dx.doi.org/10.3402/polar. v32i0.20886

Zawierucha K, Kolicka M, Takeuchi N, Kaczmarek Ł, 2015a. What animals can live in cryoconite holes? A faunal review. J. Zool. 295:159-169.

Zawierucha K, Smykla J, Michalczyk Ł, Gołdyn B, Kaczmarek $Ł, 2015 b$. Distribution and diversity of Tardigrada along altitudinal gradients in the Hornsund, Spitsbergen (Arctic). Polar Res. 34:24168. doi:10.3402/polar.v34.24168

Zawierucha K, Zmudczyńska-Skarbek K, Kaczmarek Ł, Wojczulanis-Jakubas K, 2016a. The influence of a seabird colony on abundance and species composition of water bears (Tardigrada) in Hornsund (Spitsbergen, Arctic). Polar Biol. 39:713-723.

Zawierucha K, Vonnahme TR, Devetter M, Kolicka M, Ostrowska M, Chmielewski S, Kosicki JZ, 2016b. Area, depth and elevation of cryoconite holes in the Arctic do not influence Tardigrada densities. Pol. Polar Res. 37:325-334. 